groups of faculty in highly specialized areas. Not surprisingly, these programs tended to produce narrowly focused scientists with strong orientations to research and little knowledge about teaching or other professional activities. To the extent that participants at the Convocation agreed on the future of graduate education, there seemed to be a feeling the future required greater departmental responsibility for graduate education and a broader range of professional experiences to prepare students for a full range of opportunities.

\section{Civic Education for the Next Century: A Task Force to Initiate Professional Activity}

Editor's Note: The APSA Council approved a proposal submitted by President Elinor Ostrom to create a Task Force of the American Political Science Association on Civic Education for the Next Century. This is the statement from President Ostrom about the need for political science involvement in civic education.

Serious and shocking questions about the present and future status of American democracy have recently been posed by several reflective political scientists (Putnam 1994, 1995; V. Ostrom 1991, forthcoming; Sandel 1995; Crozier 1984; Elshtain 1995). Robert Putnam identifies one of "the urgent problems of contemporary American public life" (1995: 664) as "America's stock of social capital has been shrinking for more than a quarter century" (1995: 666). Vincent Ostrom diagnoses one source of the problems as the emergence of a new "Newspeak and Doublethink" and concludes that "we in the United States and peoples in other areas of the world confront serious intellectual and cultural crises that place the future of human civilization at risk" (forthcoming, 4).

These deep concerns about the viability of democracy in America are in marked contrast to the perceptions of Alexis de Tocqueville when he visited the United States in the early 1830 s. Tocqueville described democracy in America at that time as "the great experiment of the attempt to construct society upon a new basis...." (Tocqueville [1835] 1945, I: 25). He attributed the maintenance of democracy over the first half decade of our existence to three factors, the first of which was "the manners and customs of the people" (I: 288). ${ }^{1}$ The customs of local self-organization and civic engagement, and of developing a rich pattern of local civic associations, made the system work without the kind of tutelary power found at that time in most European political systems.

Civic engagement and association can be thought of as at the core of what it means to be a democracy:

How people conduct themselves as they directly relate to one another in the ordinary exigencies of life is much more fundamental to a democratic way of life than the principle of one person, one vote, majority rule. Person-to-person, citizen-to-citizen relationships are what life in democratic societies is all about. Democratic ways of life turn on self-organizing and self-governing capabilities rather than presuming that something called "the Government governs" (V. Ostrom, forthcoming, 4).

This capacity for civic engagement and for the knowledge and use of what Tocqueville called the "science of association," has been shown in a wide diversity of recent empirical research to be closely associated with improved education, lower crime rates, higher employment and economic performance, and better performing governments (Putnam 1994).

Recent research has also shown, participation in many forms has declined dramatically and there is a substantial difference in the level and kind of participation among younger versus older citizens (McManus 1996). Civic engagement and association has steadily fallen in the United States over the past several decades.

Beyond the familiar falloff in electoral turnout, many other forms of political participation have also declined significantly over the last two decades, at the same time that political alienation and distrust in public institutions has climbed. Moreover, participation has fallen (often sharply) in many types of civic associations, from religious groups to labor unions, from women's clubs to fraternal clubs, and from neighborhood gatherings to bowling leagues. Virtually all segments of society have been afflicted by this lessening in social connectedness, and this trend, in turn is strongly correlated with declining social trust. (Putnam 1994: 1).

These disturbing patterns have many putative causes. Putnam examines a large number of potential reasons and discards many as being unrelated or spurious. He cannot, however, discard the impact of television on the privatization of American life. The advent of wide-spread ownership of television during the decades of the 1950's corresponds to the beginning of the decline of civic engagement. Increased daily viewing of television is negatively associated with group memberships across all levels of education (Putnam 1995). Not only do Americans watch an ever increasing number of hours of television in their own homes as each decade passes, but the locus of TV coverage is disconnected from the communities in which Americans live. A visitor from Mars who did no more than watch the nightly news might never gain an understanding that the United States was a strong federal system and that local communities have substantial autonomy and capabilities to cope with local problems.

Vincent Ostrom (forthcoming) points to the way that the language of authority relations has evolved in the media, in our professional publications, and in our textbooks as a complementary factor leading to a decline in citizen efficacy and involvement. Reified abstractions including the State, the Society, the Nation or even the Unemployed, the Homeless, and the Elite pepper the language of both professional political scientists and in the nightly TV news. Oversimplified abstractions and explanations do not provide citizens with the kind of knowledge and tools they need to continue the process of reconstituting a democratic way of life in the everyday life they face. A recent story on public radio described the actions of a school teacher in a community suffering industrial pollution who had all members of her grade school class write to the President of the United 
States about the pollution problems they faced in their local community. Not too many decades ago, such a teacher would have had students write to their local Mayor, to the County Council, to local industrial firms, and to the Governor of their State.

But what the teacher suggested as the way to "do something" about local industrial pollution is not too surprising given the evolution of American Government textbooks over the last several decades. When I took American Government in college, it was a two-semester course with the second semester devoted to state and local government. Now the required course that most school teachers and political science majors take is one semester long. One week-at most-is devoted to state and local government. Not only is there little attention to state and local government, there is scant attention to most forms of political and social association other than political parties. The importance of unions, professional associations, charitable and artistic associations, churches, neighborhood associations, condominiums, and self-organized sports leagues are rarely addressed. The logic of a federal system is given short attention as is the importance of the jury system even with the crucial role played by a grand jury in the Watergate scandal and of an Arkansas jury during the spring of 1996. A cardboard model of citizenship is presented that focuses primarily on voting with little emphasis on the importance of an open public realm, a culture of inquiry, and the essential role of citizens to organize for many purposes and to challenge authority.

Tocqueville had earlier warned in his chapter entitled "What Sort of Despotism Democratic Nations have to Fear," that if the citizens of a democratic nation were to act on the basis of their natural inclinations, democratic societies could evolve into a form of democratic despotism that differed from the "tyranny of the majority." Citizens might hold simplified concepts that presumed their living in a great nation where "a single and central power ... governs the whole community by its direct influence" and "composed of citizens all formed upon one pattern and governed by a single power."2

Until recently, the views of many policy analysts have been consistent with Tocqueville's worst image of the future of democratic societies. Using the metaphor of the "tragedy of the commons," the "collectiveaction problem," and the Prisoners' Dilemma game, many policy analysts viewed citizens as trapped in inexorable dilemmas and tragedies. According to some "the only way out" is the imposition of Leviathan. According to others, "the only way out" is the creation of a market. Both have to be imposed from the outside by a national government on citizens who are perceived as helpless pawns. Rigorous theoretical work and empirical studies in both field settings and experimental labs have established that there exist a wide diversity of ways that citizens communicate with one another about joint problems, organize themselves, adopt norms and rules, monitor and enforce these rules, and cope effectively with social dilemma type situations. ${ }^{3}$ Not all such efforts are successful, but neither are all efforts to impose solutions from the outside. We have much to learn from theoretical and empirical studies of the conditions that facilitate citizens solving their own collective action problems.

\section{What Can a Task Force Do?}

These reflections point to a multiplicity of vulnerabilities. No single project could address all of these. However, one of the core problems identified by many serious scholars focusing on contemporary problems is the decline in civic engagement, political efficacy, and the capacity of citizens to organize themselves rather than to rely on others to solve problems for them. Developing a variety of educational tools-drawing on reliable and valid empirical findings and effective analytical approaches, encouraging and supporting new empirical studies where needed, and utilizing both traditional and new forms of presentations-is something that a Task Force can design and implement over time. Since it is four years until the beginning of the 21st Century and seven years until the beginning of the Second Century of the American Political Science Association, there is time to think, develop, test, evaluate, and reformulate a diversity of educational tools that provide more effective forms of civic education.

\section{Stimulate the Preparation of Teaching Materials}

Thus the objective of the Task Force is to address the need for civic education and civic engagement by teaching students the theory, purposes, and skills of involvement in a wide range of voluntary associations and governing agencies in their own communities as well as in larger political entities. Students need to learn both the short-term and longterm costs and benefits of civic engagement and the risks and rewards of diverse kinds of civic engagement. Learning effective skills of citizen involvement and responsibility are critical to a fully representative democracy. High school and lower division students can learn and practice these skills in the classroom and in their own communities. We need to balance the all too considerable emphasis in recent educational materials on national government and national elections as the primary source of civic engagement for
The Task Force on Civic Education for the Next Century is eager to locate political scientists who are doing research on civic education or are involved in civic education programs. Please send your name, address, and a description of your activity, identifying its audience and level of education to: Sheilah Mann, Director of Educational Programs, American Political Science Association, 1527 New Hampshire Avenue, NW, Washington, DC 20036; Phone: (202) 483-2512; or E-mail: smann@apsa.com. 
American citizens. Research by political scientists, as well as other social scientists, on the structure, procedures, incentives, and

consequences of group and organizational activities that are broadly involved in governance will be the source of information for this new civic education effort. We will as well review prior efforts to enhance civil education in our own effort to learn from past experience. ${ }^{4}$

The project will develop instructional designs, resources, and even specific "lessons." A considerable emphasis will be placed on the kinds of research that students can undertake in their own communities that enhance their knowledge about local political entrepreneurs, the types of problems faced in local communities, and the types of participation that strengthen problem solving versus those that impede progress toward better solutions. The audience will be students in 11th-12th grade high school government courses, community college students, and lower division students. Materials will be developed for "traditional" courses and to accompany service learning programs. These materials may be developed by the Task Force itself, by subcommittees of the Task Force, or by other educational projects who have similar goals and with whon the Task Force can develop collaborative relationships. The Task Force and those with whom the Task Force may collaborate may also organize conferences and workshops that address these issues.

\section{Membership of the Task Force}

The membership of the Task Force includes the following:

Melvin J. Dubnick, Rutgers University, Newark, Co-Chair

Jean Bethke Elshtain, University of Chicago, Co-Chair

Leif $\mathrm{H}$. Carter, Colorado College

Mary Hepburn, University of Georgia

Donald Lutz, University of Houston

Susan MacManus, University of South Florida

Ronald Oakerson, Houghton College

Robert D. Putnam, Harvard University
Edward Thompson, III, California State University, San Marcos

Elinor Ostrom, President-Elect, APSA

Sheilah Mann, Director, Education Programs, APSA

\section{Time Line for the Task Force}

The Task Force will be appointed during the summer of 1996. Once appointed, the members of the Task Force will be asked to exchange several of their own publications that are relevant, a short reading list, and ideas for how to proceed with the activities of the Task Force, with the other members of the Task Force. The first meeting of the Task Force will be at the 1996 APSA meetings in San Francisco. During the 19961997 academic year, the Task Force will continue to exchange information and views and develop a set of Task Force Recommendations by the 1997 APSA meetings in Washington, D.C. During the fall of 1997 , the Task Force will hold a Workshop (possibly as a Wingspread Conference) to respond to and elaborate on the Task Force Recommendation and to make specific plans for developing instruction materials. During 1998 and 1999, efforts will be devoted to materials development and outreach. During 2000-2002, these materials will be disseminated and evaluated so that they are ready for more widespread use in 2003 when the APSA is starting its second century. In 2005, the Task Force will complete its work with a major report on an evaluation of the materials and suggestions for further refinement and continuing support of the process.

\section{Sources of Funding}

The Task Force would become one of the sub-projects associated with the Centennial Campaign of the APSA. Since civic education was an initial, foundational objective in the establishment of the APSA, the "Civic Education for the Next Century," is a fitting component of the Campaign.

\section{Notes}

1. The second major factor was "the laws" (ibid., 288) including the federal form of government, the township institutions "which limit the despotism of the majority and at the same time impart to the people a taste for freedom and the art of being free" (ibid., 299) and the constitution of the judicial power, particularly the regular participation of citizens on juries. The third major factor was the size and distance of the American continent from European powers.

2. As Tocqueville pictured the fearsome consequence of an unthinking evolution that could befall democratic societies:

The first thing that strikes the observer is an innumerable multitude of men, all equal and alike, incessantly endeavoring to procure the petty and paltry pleasures with which they glut their lives. Each of them, living apart, is as a stranger to the fate of all the rest; his children and his private friends constitute to him the whole of mankind. As for the rest of his fellow citizens, he is close to them, but he does not see them; he touches them, but he does not feel them; he exists only in himself and for himself alone; and if his kindred still remain to him, he may be said at any rate to have lost his country.

Above this race of men stands an immense and tutelary power, which takes upon itself alone to secure their gratifications and to watch over their fate. That power is absolute, minute, regular, provident, and mild. It would be like the authority of a parent if, like that authority, its object was to prepare men for manhood; but it seeks, on the contrary, to keep them in perpetual childhood: it is well content that the people should rejoice, provided they think of nothing but rejoicing. For their happiness such a government willingly labors, but it chooses to be the sole agency and the only arbiter of that happiness; it provides for their security, foresees and supplies their necessities, facilitates their pleasures, manages their principal concerns, directs their industry, regulates the descent of property, and subdivides their inheritances: what remains, but to spare them all the care of thinking and all the trouble of living (Tocqueville [1840] 1945, II: 318).

3. See McCay and Acheson, 1987; Fortmann and Bruce, 1988; Wade, 1988; Berkes, 1989; Pinkerton, 1989; E. Ostrom, 1990; 1992; Sengupta, 1991; Bromley, 1992; Blomquist, 1992; Tang, 1992; Martin, 1989/1992; Thomson, 1992; V. Ostrom, Feeny and Picht, 1993; E. Ostrom, Gardner, and Walker, 1994; Keohane and E. Ostrom, 1995.

4. See, for example, Merriam 1931; 1934.

\section{References}

Berkes, Fikret, ed. 1989. Common Property Resources. Ecology and Community-Based Sustainable Development. London: Belhaven Press. 
Blomquist, William. 1992. Dividing the Waters: Governing Groundwater in Southern California. San Francisco, CA: Institute for Contemporary Studies Press.

Bromley, Daniel W., ed. 1992. Making the Commons Work: Theory, Practice, and Policy. San Francisco, CA: Institute for Contemporary Studies Press.

Crozier, Michel. 1984. The Trouble with America: Why the System is Breaking Down. Berkeley: University of California Press.

Elshtain, Jean. 1995. Democracy on Trial. New York: Basic Books.

Feeny, David, Fikret Berkes, Bonnie J. McCay, and James M. Acheson. 1990. "The Tragedy of the Commons: Twenty-Two Years Later." Human Ecology 18(1):1-19.

Fortmann, Louise, and John W. Bruce, eds. 1988. Whose Trees? Proprietary Dimensions of Forestry. Boulder, CO: Westview Press.

Haas, Peter, Robert O. Keohane, and Marc A. Levy. 1993. Institutions for the Earth. Sources of Effective International Environmental Protection. Cambridge, MA: MIT Press.

Hardin, Garrett. 1968. "The Tragedy of the Commons." Science 162:1243-48.

Hardin, Russell. 1982. Collective Action. Balti more, MD: Johns Hopkins University Press.

Keohane, Robert O., and E. Ostrom, eds. 1995. Local Commons and Global Interdependence: Heterogeneity and Cooperation in Two Domains. Sage Publications.

MacManus, Susan A. 1996. Young v. Old Generational Combat in the 21st Century. Boulder: Westview Press.

McCay, Bonnie J. and James M. Acheson. 1987. The Question of the Commons: The Culture and Ecology of Communal Resources. Tucson: University of Arizona Press.

Merriam, Charles E. 1931. The Making of Citizens. Chicago: University of Chicago Press.

Merriam, Charles E. 1934. Civic Education in the United States. New York: Charles Scribner's Sons.

Olson, Mancur. 1965. The Logic of Collective Action. Public Goods and the Theory of Groups. Cambridge, MA: Harvard University Press.

Ostrom, Elinor. 1990. Governing the Commons: The Evolution of Institutions for Collective Action. Cambridge, MA: Cambridge University Press.

Ostrom, Elinor. 1992. Crafting Institutions for Self-Goverming Irrigation Systems. ICS Press.

Ostrom, Elinor, Roy Gardner, and James Walker. 1994. Rules, Games, and Common-Pool Resources. Ann Arbor: University of Michigan Press.

Ostrom, Elinor, James Walker, and Roy Gardner. 1992. "Covenants With and Without a Sword: Self-Governance Is Possible." American Political Science Review 86(2) (June): 404-17.

Ostrom, Vincent. 1991. The Meaning of American Federalism: Constituting a Self-Governing Society. San Francisco: Institute for Contemporary Studies Press.

Ostrom, Vincent. (Forthcoming) The Meaning of Democracy. The Vulnerability of Democracies. Ann Arbor, MI: University of Michigan Press.

Ostrom, Vincent, David Feeny, and Hartmut
Picht, eds. 1993. Rethinking Institutional Analysis and Development: Issues, Alternatives, and Choices. 2d ed. San Francisco, CA: Institute for Contemporary Studies Press.

Pinkerton, E. 1989. Co-operative Management of Local Fisheries. New Directions for Improved Management and Community Development. Vancouver: University of British Columbia Press.

Putnam, Robert D. 1994. "Bowling Alone: Democracy in America at the End of the Twentieth Century." Cambridge, MA: Harvard University, manuscript.

Putnam, Robert D. 1995. "Tuning In, Tuning Out: The Strange Disappearance of Social Capital in America." PS: Political Science \& Politics xx(1) (Dec.): 664-83.

Sandel, Michael J. 1996. Democracy's Discontent. America in Search of a Public Philosophy. Cambridge: Harvard University Press.

Sandler, Todd. 1992. Collective Action. Ann Arbor: University of Michigan Press.

Sengupta, Nirmal. 1991. Managing Common Property: Irrigation in India and the Philippines. London: Sage.

Tang, Shui Yan. 1992. Institutions and Collective Action: Self-Governance in Irrigation. San Francisco, CA: Institute for Contemporary Studies Press.

Thomson, James T. 1992. A Framework for Analyzing Institutional Incentives in Com munity Forestry. Rome: Food and Agriculture Organization of the United Nations.

Tocqueville, Alexis de. [1835 and 1840] 1945. Democracy in America. 2 vols., ed. Phillips Bradley, New York: Alfred A. Knopf.

Wade, Robert. 1988. Village Republics: Economic Conditions for Collective Action in South India. Cambridge University Press.

Walzer, Michael. 1994. "Multiculturalism and Individualism." Dissent (Spring).

\section{Report of the Editor of the American Political Science Review, 1995-96}

Ada W. Finifter, Michigan State University

The first year of my term as Editor of the American Political Science Review has been enormously exciting, challenging, and stimulating. Above all, it has been very busy! More manuscripts were submitted than in any of the previous ten years. Editorially, the Review continues to have the same goals it has always had: to publish the best original research in the discipline, demonstrating the highest standards of excellence in conceptualization, exposition, methodology, and craftsmanship and having the potential to contribute to the development of general theory in political science. While dealing with the continual heavy flow of papers to be reviewed, we were, at the same time, developing new procedures, new ways of serving and communicating with authors, reviewers, and readers, and making some changes in the physical appearance of the journal.

Although the colors have been freshened, and numerous small changes (detailed below) have been made, the Review looks much the same as it has since its size was enlarged four years ago. The former Controversy section of the Review has been renamed Forum and given a broader definition, to include not only critiques and commentary on previously published articles but also other articles that discuss research issues in the discipline. A few articles along those lines have already been published; readers are invited to submit others, including analytic literature reviews and discussions of research problems. I have also instituted a procedure of forwarding critiques of previously published articles to the authors being critiqued as soon as they are received so that critiqued authors will be alerted to the possibility of their publication and can begin to think at the earliest possible date about how they might reply. Critiques and commentaries on previously published articles go through the regular review process with a normal complement of reviewers, but, in addition, critiqued authors are invited to send comments to the Editor. Given its importance to most readers, the Book Review section has been given some increased attention in our formatting and page count.

In the report that follows I will provide some details on all these activities.

\section{Submissions}

Table 1 demonstrates that the number of submissions (and therefore the workload of the editorial office) has increased dramatically over the last decade. We received $25 \%$ more manuscripts this past year than the average number received during the last five years of the Patterson editorship, $10 \%$ more than the average annual number received during the four-year Powell editorship, and $8 \%$ more than received 